\title{
The Impact of IL-6 and IL-10 Gene Polymorphisms in Diffuse Large B-Cell Lymphoma Risk and Overall Survival in an Arab Population: A Case-Control Study
}

\author{
Sohaib M. Al-Khatib ${ }^{1, *(\mathbb{D},}$, Nour Abdo ${ }^{2}$, Laith N. AL-Eitan ${ }^{3}{ }^{\mathbb{D}}$, Abdel-Hameed Al-Mistarehi ${ }^{4}(\mathbb{D}$, \\ Deeb Jamil Zahran ${ }^{5}$ and Tariq Zuheir Kewan ${ }^{5,6}$ \\ 1 Department of Pathology and Laboratory Medicine, Faculty of Medicine, Jordan University of Science and \\ Technology, Irbid 22110, Jordan \\ 2 Department of Public Health, Faculty of Medicine, Jordan University of Science and Technology, \\ Irbid 22110, Jordan; nmabdo@just.edu.jo \\ 3 Department of Biotechnology and Genetic Engineering, Faculty of Science and Arts, \\ Jordan University of Science and Technology, Irbid 22110, Jordan; lneitan@just.edu.jo \\ 4 Department of Family Medicine, Faculty of Medicine, Jordan University of Science and Technology, \\ Irbid 22110, Jordan; awalmistarehi18@med.just.edu \\ 5 Department of Internal Medicine, Faculty of Medicine, Jordan University of Science and Technology, \\ Irbid 22110, Jordan; djzahran16@med.just.edu.jo (D.J.Z.); kewant@ccf.org (T.Z.K.) \\ 6 Department of Internal Medicine, Cleveland Clinic Foundation, Cleveland, OH 44109, USA \\ * Correspondence: smkhatib4@just.edu.jo; Tel.: +962-799-409933; Fax: +962-2-72006262
}

Received: 3 December 2019; Accepted: 5 February 2020; Published: 7 February 2020

\begin{abstract}
B-cell lymphomas can be classified as Hodgkin and non-Hodgkin lymphomas. Diffuse large B-cell lymphoma (DLBCL) is the most common non-Hodgkin Lymphoma (NHL). The incidence of NHL is variable and affected by age, gender, racial, and geographic factors. There is strong evidence that the immune-regulatory cytokines have a major role in hematologic malignancies. In this study, we analyzed the relationship between seven single nucleotide polymorphisms (SNPs) in two selected cytokines (IL-6 rs1800795G > C, rs1800796G > C, rs1800797G > A, IL-10 rs1800871G > A, rs1800872G > T, rs1800890A > T, rs1800896T $>$ C) and the risk and overall survival of DLBCL patients in a Jordanian Arab population. One hundred and twenty-five DLBCL patients diagnosed at King Abdullah University Hospital (KAUH) from the period 2013-2018 and 238 matched healthy controls were included in the study. Genomic DNA was extracted from formalin-fixed paraffin-embedded tissues. Genotyping of the genetic polymorphisms was conducted using a sequencing protocol. Our study showed no significant differences in the distribution of all studied polymorphisms of DLBCL between patients and controls. The IL-6 rs1800797 was the only SNP to show significant survival results, DLBCL subjects with the codominant model (GG/AG/AA) genotypes and recessive model (AA genotype in comparison with the combined GG/GA genotype) had worse overall survival $(p=0.028$ and 0.016 , respectively).
\end{abstract}

Keywords: diffuse large B-cell lymphoma; single nucleotide polymorphism; IL-6; IL-10; Arab population

\section{Introduction}

Mature B-cell lymphomas are divided into Hodgkin and non-Hodgkin Lymphomas (HL and NHL) [1]. NHL is considered the sixth most common type of cancer and the ninth leading cause of cancer deaths among both males and females [2,3]. The trends of incidence for NHL are variable and show significant age, gender, racial, and geographic differences [4-8]. The surrounding environment, 
infectious microorganisms, and lifestyle all play an important role in NHL pathogenesis [9-12]. Diffuse large B-cell lymphoma is the most common NHL [13]. Diffuse large B-cell lymphoma (DLBCL) is a diverse disease and genetically can be classified into two distinct types; the germinal center B-like type, characterized by the expression of germinal center B-cell genes, and the activated B-like type which shows gene expression of activated peripheral blood B cells. Clinically, the germinal center B-like type shows better overall survival [14].

Several studies reveal that the immune-regulatory cytokines have a major role in hematologic malignancies. T-lymphocytes, natural killer cells, macrophages, dendritic cells, and tumor-associated T-lymphocytes are the key components of the tumor inflammatory milieu. Recruitment of inflammatory cells to the site of inflammation is mediated by cytokines. Cytokines are a diverse group of low molecular weight regulatory, mostly soluble, proteins or peptides. Cytokines contribute to cell-to-cell communication, orchestrate the inflammatory and immune responses, act alone, and their secretion is induced by different stimuli. Cytokines are classified according to their molecular structure or function. Structurally, cytokines can be classified into four families: the IL-1 family, the IL-17 family, the tumor necrosis factor (TNF) family, and the four alpha-helix family which includes IL-2, interferon (INF), and IL10. Functionally, cytokines are either part of antibody-mediated (humoral) immunity or cellular-mediated immunity [15].

A number of studies have evaluated the association between specific polymorphisms of IL-6 and IL-10 genes and the risk of non-Hodgkin lymphoma. Fewer studies analyzed the impact of IL-6 and IL-10 polymorphisms on the prognosis of patients with DLBCL [16-18].

The serum level of IL-10 affects the overall survival of patients with both HL and NHL. NHL patients with polymorphisms at positions (IL10-3575 T > A rs1800890) and (IL10-1082 A > G rs1800896) show better overall survival $(p=0.002)$ and median overall survival $(p=0.05)$, respectively $[19,20]$. However, no study has yet described the association between IL-6 and IL-10 gene polymorphisms and the risk and overall survival among an Arab population.

The aim of this study was, therefore, to analyze the relationship between seven, previously studied, single nucleotide polymorphisms (SNPs) in two selected cytokines (IL-6 rs1800795G > C, rs1800796G > C, rs1800797G > A, IL-10 rs1800871G > A, rs1800872G > T, rs1800890A > T, rs1800896T > C) and the risk and overall survival of DLBCL patients in a Jordanian Arab population.

\section{Results}

\subsection{Demographic and Clinical Data}

A total of 363 DNA samples were included in this study, namely, 238 healthy controls and 125 DLBCL patients. Among the patients, 66 (52.8\%) were males and $59(47.2 \%)$ were females. Of the control subjects, $92(38.7 \%)$ were males and $146(61.3 \%)$ were females. The age range for the patients was 15-89 years with a mean age of 53.7 years. The mean age for the controls was 43.2 years (6-89). Table 1 summarizes patients' demographic and clinical data.

\subsection{Association Between IL-6 and IL-10 Gene Polymorphisms and the Risk of DLBCL}

The genotype distributions for all the SNPs in both 125 DLBCL patients and 238 control subjects were in Hardy-Weinberg equilibrium (HWE) and normally distributed with $p$-value $>0.05$. The HWE $p$-values for the cases and the controls are shown in Table S1.

The distribution of both genotypic frequencies and allelic frequencies of IL-6 rs1800795G $>$ C, rs1800796G > C, rs1800797G > A, IL-10 rs1800871G > A, rs1800872G > T, rs1800890A > T, rs1800896T > C SNPs showed no significant differences in the distributions of all studied polymorphisms of IL-6 and IL-10 among DLBCL patients and controls ( $p=0.87,0.80,0.83,0.76,0.81,0.42$, and 0.78 ), respectively. Table S2. 
Additional analyses based on four genetic models (codominant, dominant, recessive, and overdominant) were performed on all the SNPs and the results show no significant association between any of the genetic models and the risk of DLBCL. The results are shown in Table S3.

Table 1. Demographic and clinical data of 125 diffuse large B-cell lymphoma (DLBCL) patients of Jordanian Arab descent in this study.

\begin{tabular}{|c|c|c|}
\hline Category & Value N(\%) & \\
\hline Demographic Data & Cases & Controls \\
\hline \multicolumn{3}{|l|}{ Gender } \\
\hline Male & $66(52.8)$ & $92(38.7)$ \\
\hline Female & $59(47.2)$ & $146(61.3)$ \\
\hline \multicolumn{3}{|l|}{ Age in Years * } \\
\hline $0-14$ & $(0.0)$ & $3(1.3)$ \\
\hline $15-19$ & $8(6.4)$ & $18(7.6)$ \\
\hline $20-40$ & $18(14.4)$ & $89(37.4)$ \\
\hline $41-55$ & $31(24.8)$ & $59(24.8)$ \\
\hline$>55$ & $68(54.4)$ & $69(28.9)$ \\
\hline Mean (Range) & $53.7(1-89)$ & $43.2(6-89)$ \\
\hline Median (IQR) & $57(44-66)$ & $44(24.2-57)$ \\
\hline \multicolumn{3}{|l|}{ Clinical Data } \\
\hline \multicolumn{3}{|l|}{ Survival Status } \\
\hline Alive & $69(55.2)$ & - \\
\hline Dead & $56(44.8)$ & - \\
\hline Survival Months & & - \\
\hline Median & 55 & - \\
\hline \multicolumn{3}{|l|}{ B-Symptoms } \\
\hline Yes & $15(14.9)$ & - \\
\hline No & $86(85.1)$ & - \\
\hline \multicolumn{3}{|c|}{ Ann Arbor Stage at Diagnosis } \\
\hline 0 & $2(1.6)$ & - \\
\hline 1 & $25(20)$ & - \\
\hline 2 & $9(7.2)$ & - \\
\hline 3 & $11(8.8)$ & - \\
\hline 4 & $74(59.2)$ & - \\
\hline Unknown & $4(3.2)$ & - \\
\hline \multicolumn{3}{|l|}{ Serum LDH } \\
\hline Mean (Range) & $635(2-4422)$ & - \\
\hline Median (IQR) & $423(194.5-790)$ & - \\
\hline Total Protein & & - \\
\hline Mean (Range) & $58.6(4-93.3)$ & - \\
\hline Median (IQR) & $65.8(57-73)$ & - \\
\hline Serum Albumin & & - \\
\hline Mean (Range) & $35.4(3-87.8)$ & - \\
\hline Median (IQR) & $38.4(33-43)$ & - \\
\hline \multicolumn{3}{|l|}{ Total Monocytes } \\
\hline Mean (Range) & $6.9(1-22)$ & - \\
\hline Median (IQR) & $6.3(4.3-8.5)$ & - \\
\hline
\end{tabular}

* Age of controls vs. age at diagnosis in cases. Competition. 


\subsection{Association between IL-6 and IL-10 Gene Polymorphisms and the Survival Rate of DLBCL}

The survival analysis for all 125 DLBCL patients was performed using the Kaplan-Meier curve and log-rank test/Wilcoxon (Gehan) statistic. The IL-6 rs1800797 was the only SNP to show significant survival results. In our study, the subjects with the codominant model (GG/AG/AA) genotype and recessive model (AA genotype in comparison with the combined GG/GA genotype) had worse overall survival (OS) ( $p=0.028$ and 0.016), respectively, as shown in Figure 1.
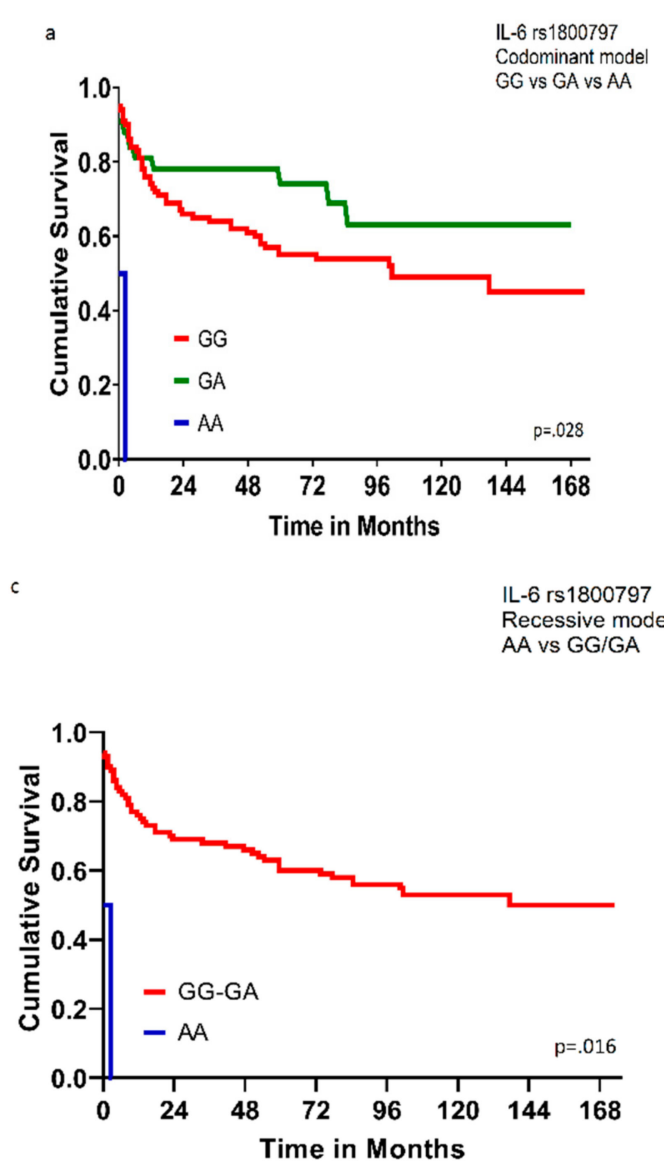

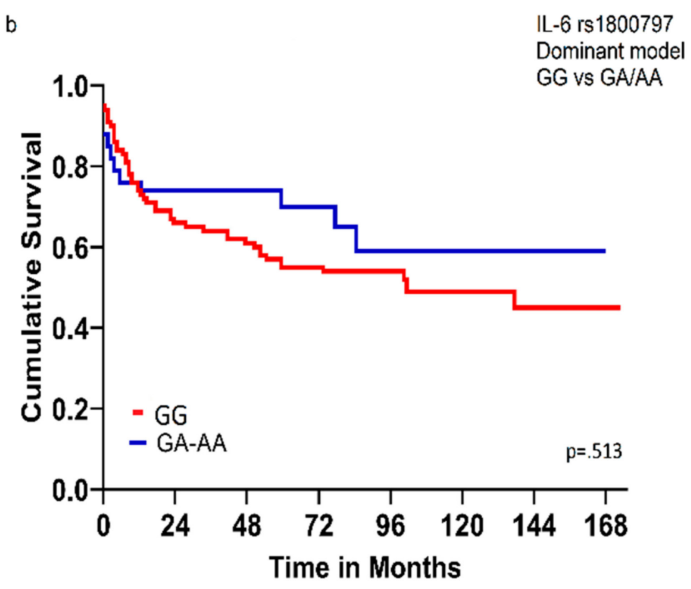

d

IL-6 rs1800797 Overdominant model GA vs GG/AA

Figure 1. Overall survival for 125 DLBCL patients according to genotype of IL-6 rs1800797. (a) Comparison among GG, GA, and AA genotypes; codominant model ( $p=0.028)$. (b) Comparison between GG genotype and combined GA/AA genotypes; dominant model ( $p=0.513)$. (c) Comparison between AA genotype and combined GG/GA genotypes; recessive model $(p=0.016)$. (d) Comparison between GA genotype and combined GG/AA genotypes; overdominant model $(p=0.173)$. Wilcoxon (Gehan) Statistic $p$ values were indicated.

\section{Discussion}

Many cells, including macrophages, B-lymphocytes, T-lymphocytes, mast cells, endothelial cells, fibroblasts, and stromal cells produce cytokines. However, one cytokine can be produced by more than one cell type and the action of one cytokine can be inhibited by another cytokine. The effect of cytokines is pleiotropic, redundant, and synergized; in other words, one cytokine has different effects on different cell types or different cytokines have the same or exaggerated effect [21]. The main function of cytokines is to modulate the inflammatory response by regulating hematopoiesis, innate, and acquired immunity. They control the growth, differentiation, and survival of different cell populations, including inflammatory cells [22]. Cytokines cannot cross the cell lipid bilayered 
membrane and they exert their function of cell signaling through receptors. Six groups of receptors have been recognized; the immunoglobulin superfamily receptors, the hematopoietin receptor family (Class I cytokine receptor family), the Interferon receptor family (Class II cytokine receptor), the TNF receptor family, the IL-17 receptor family, and the chemokine receptor family [23]. The signaling pathways for cytokines' receptors include the nuclear factor kappa B (NF-kB), JAK/STAT, and G protein pathways [24,25].

Lymphomagenesis is a complex process that incorporates interaction between the tumor cells and the surrounding stromal cells or extracellular matrix [26]. The inflammatory milieu which incorporates the host inflammatory cells is supposed to exert an immune protective antitumor activity and the pro-inflammatory cytokines should be followed rapidly by the anti-inflammatory cytokines to eradicate inflammation. In cancers, the net balance between immune-mediated antitumor activity and tumor-induced immune suppression is skewed toward the latter [27]. The immune avoidance of tumor cells is a key factor in cancer progression, invasion, and metastasis [28].

Although cytokines may not be involved in early steps of B-cell transformation and lymphoma development, they play an important role in inducing malignant B-cell survival and proliferation and the level of many cytokines is aberrantly elevated in different hematologic malignancies [29-32]. In addition, cytokine secretion is influenced by the level of gene expression which is determined by host genetic variation or gene polymorphism [33]. The expression and secretion of IL-6 and IL-10 as determined by SNP is associated with risk of developing and or OS of lymphomas [31,34,35].

IL- 6 or interferon beta 2 is a $21 \mathrm{kDa}, 212$ amino acid, monocyte-derived glycoprotein, mapped to chromosome 7 (7p15.3), and assembled as a hexameric complex that includes IL-6, the IL-6 $\alpha$-receptor (IL-6R $\alpha)$, and the shared signaling receptor gp130 [36,37]. IL-6 is a pyrogenic, pro-inflammatory, and immune-regulatory cytokine involved in defending the host against infections by stimulating the differentiation of and immunoglobulin synthesis by B-lymphocytes. Although monocyte is the major source for IL-6, it can be produced by many cells including dendritic cells, lymphocytes, neutrophils, mast cells, mesenchymal and stromal cells, glial cells, and tumor cells.

The activation of the innate immune system is a prerequisite and a fundamental step for the initiation of acquired immunity. An essential step in innate immunity response to invading pathogens is to differentiate between self and foreign pathogens, this is done by recognizing biomolecules exclusively found and expressed by the pathogen. These biochemical molecules are proteins, lipids, or sugar signatures known as pathogen-associated molecular patterns (PAMPs) [38]. The immune cells recognize PAMPs by a group of receptors known as pattern recognition receptors (PRRs) which include Toll-like receptors (TLRs), RIG-I-like receptors (RLRs), NOD-like receptors (NLRs), C-type lectin-like receptors (CLRs), and DNA sensors [39].

TLRs are noncatalytic, type 1, transmembrane glycoproteins expressed on macrophages and dendritic cells and recognize conserved structure in the pathogen. In humans, 10 functional TLRs are identified, namely, TLR1-TLR10. The biological responses of each TLR are heterogeneous because the signaling pathways associated with each TLR are not equal $[40,41]$. The signaling molecules used by the TLRs are either myeloid differentiation primary response gene 88 (MyD88)-dependent or -independent and include MyD88, IL-1R-associated protein kinase, and TNF receptor-activated factor 6. The MyD88-dependent pathway activation leads to the activation of NF- $\kappa \mathrm{B}$ transcription factor, which results in the production of pro-inflammatory cytokines [41,42].

Many studies show that IL-6 gene promoter polymorphism (rs1800795G > C) is associated with the risk for developing both neoplastic and non-neoplastic diseases, including Kaposi sarcoma, intracranial hemorrhage, diabetes mellitus, osteoporosis, and Crohn's disease [43-47]. However, the relationship between IL-6 gene promoter polymorphism and the risk of lymphomas shows inconsistent results. A popular case-control study to assess the relationship between gene polymorphisms and the risk of lymphoma done by the International Lymphoma Epidemiology (InterLymph) consortium in 2006 showed that there is no association between IL-6 promoter polymorphism (174G > C rs1800795) and the risk of NHL [16]. The same conclusion was reached by three more studies; two on Caucasians and 
one on an Egyptian Arab population which found no association between IL6 rs1800795 (174 G > C) and IL6 rs1800797 (597/598G > A) gene polymorphism and the risk of NHL [48-50]. In contrast, Gu et al. found that, in the Han Chinese population, the risk of NHL, in particular, multiple myeloma, is positively associated with IL-6 rs1800795 (GC versus GG: OR = 3.976, 95\% CI: 1.400-11.295, $p=0.006$ ) and IL-6 rs1800797 (GA versus GG: OR = 3.976, 95\% CI: 1.400-11.295, $p=0.006$ ) polymorphisms [17]. Consistent with Gu's result, Ennas et al. found that (IL6-174G > C rs1800795) gene polymorphism is positively associated with the risk of chronic lymphocytic leukemia [18]. The conflicting results may be attributed partially to ethnic and racial factors. In our study on a Jordanian Arab population, the results are consistent with what was found with Caucasians where no significant correlation between the three SNPs (rs1800795G > C, rs1800796G > C, rs1800797G > A) of the IL-6 gene promoter and the risk and OS of DLBCL is present. However, the same thing does not apply to survival findings. In our study, we found that IL-6 rs1800797 SNP shows significant survival results, subjects with the codominant model (GG/AG/AA) genotypes and recessive model (AA genotype in comparison with the combined GG/GA genotype) had worse OS ( $p=0.028$ and 0.016 , respectively) than the others.

Interleukin 10 (IL-10), or human cytokine inhibitory factor is a homodimer, pleiotropic anti-inflammatory cytokine that is encoded by the IL-10 gene, which is mapped to chromosome $1 q$ in the junction between 1q31 and 1q32 (1q32.1) [51]. IL-10 is mainly produced by monocytes and acts as anti-inflammatory cytokine by reducing the expression of IL-6 through a receptor complex that inhibits ERK1/2 and NF-KB activation and induces a STAT3 signaling pathway [52]. In addition, IL-10 conducts its anti-apoptotic activity by inducing the expression of human leukocyte antigen G (HLA-G) which inhibits Th1-type cytokines such as TNF-a and IFN-c [53,54].

The expression level of IL-10 messenger RNA is influenced by polymorphisms affecting both the proximal (rs1800872A > C, rs1800890A > T, rs1800896A > G) and the distal (rs1800871T > C) region of IL-10 promoter gene [55]. As a result, IL-10-1082G allele (rs1800896) is associated with high IL-10 production and IL-10-1082A allele (rs1800896) is associated with low IL-10 production [56]. The association between IL-10 gene polymorphisms and IL-10 production and the risk of developing and/or the OS of aggressive NHL is conflicting. In studies done over Chinese populations, the G allele of IL-10 rs1800896 SNP was found to be associated with increased risk of DLBCL [57]. However, other studies show that the low-level IL-10-producing genotypes (-3575A allele of rs1800890 and -1082A allele of rs1800896) show more association with DLBCL [34,58]. The association between the clinical outcome and IL-10 gene polymorphisms in DLBCL also shows different results between different studies and different people. Lech-Maranda et al. reported that DLBCL patients with the presence of G allele (IL-10-1082AG/GG genotype compared to 1082AA genotype) show improved overall survival and a higher rate of complete remission. On the contrary, Mattias Berglund et al. on their study over 168 de novo DLBCL cases found no difference in overall survival between patients with the IL-10-1082AG/GG genotype and patients with the IL-10-1082AA genotype [34,59].

The studies on the relationship between IL-10 rs1800871 C/T and DLBCL risk and overall survival show heterogeneity and inconsistent results among different ethnic groups. Four studies on Caucasians/mixed population done by Lech-Maranda et al., Lan et al., Rothman N et al., and Purdue et al. found no significant association between IL-10 rs1800871 T > C polymorphism and risk of DLBCL in all comparison models $[16,34,48,60]$. However, Lim et al. in their study over three major races of Malaysian population are the only to show that rs1800871 $\mathrm{T}>\mathrm{C}$ polymorphism in the recessive model is associated with increased risk of all types of NHL including DLBCL among Malays $(p=0.007)$ and Chinese $(p=0.039)$ but not Indians $(p=0.991)$ [61]. The reasons for the inconsistency in results are uncertain and may be attributed to the variation in mutant alleles frequencies between different populations and ethnic groups (rs1800871, Malay minor allele frequency $(\mathrm{MAF})=0.25$; Chinese MAF = 0.27; Indian MAF = 0.37) compared to the Caucasian population in the Rothman et al. study (rs1800871 MAF = 0.75). However, the differences in allelic frequency between ethnicities should not be the only reason responsible for inconsistent results between IL-10 SNPs and susceptibility to DLBCL as heterogeneity is still observed despite consistent allelic frequencies (rs1800871, MAF =0.32, 0.24, 0.22, 
and 0.27) for Caucasian populations in Lech-Maranda et al., Lan et al., Purdue et al., and our Jordanian population, respectively, compared to Malaysian populations in the Lim et al. study.

Patient characteristics, treatment options, the dual biological function of IL-10, and the variation in mutant alleles frequencies between different populations and ethnic groups should all be responsible for the inconsistency in the relationship between IL-10 SNPs and DLBCL risk and outcome.

\section{Material and Methods}

\subsection{Patients and Data Collection}

The study population was composed of 125 patients and 238 healthy cancer-free control subjects with similar geographic and ethnic backgrounds to the patients. The 125 cases of DLBCL were retrieved from the archives of King Abdullah University Hospital during the period of 2013-2018. All cases were reviewed by (SK) and one representative section was chosen from each case. All the procedures performed were approved by the ethical committee of Jordan University of Science and Technology (Institutional Review Board (IRB) code number 5/106/2017, dated 8 June 2017) in accordance with the 1964 Declaration of Helsinki and its later amendments. Formal written informed consent was not required with a waiver by the IRB. All control subjects were voluntarily involved and signed written informed consent. Cases' and controls' names were coded and blinded and treated confidentially.

\subsection{DNA Analysis}

Genomic DNA was extracted for the DLBCL patients from formalin-fixed paraffin-embedded tissue using a commercially available kit, DNeasy Blood and Tissue Kit (Qiagen Ltd., West Sussex, UK), using the manufacturer's protocols. Genomic DNA from control-subjects' blood samples was extracted using the QIAamp ${ }^{\circledR}$ or Promega DNA Mini Kit according to the manufacturer's instruction. The quality of extracted DNA was examined using agarose gel electrophoresis and ethidium bromide staining. The concentration and purity of extracted DNA were assessed using a NanoDrop $1000^{\circledR}$ spectrophotometer. The pure DNA samples with their concentrations were sent to the Australian Genome Research Facility (AGRF, Melbourne Node, Melbourne, Australia) for genotyping of seven SNPs in two cytokines' genes (IL-6 rs1800795G > C, rs1800796G > C, rs1800797G > A, IL-10 rs1800871G $>$ A, rs1800872G > T, rs1800890A > T, rs1800896T > C) in all subjects (patients and controls). The SNPs, SNPs' position, and primer sequences for IL-6 and IL-10 genes are shown in Table 2. Genotyping with the Sequenom MassARRAY ${ }^{\circledR}$ system (iPLEX GOLD) (Sequenom, San Diego, CA, USA) was performed at the AGRF according to the manufacturer's recommendations (Sequenom, San Diego, CA, USA). Genotype distributions were compared between patients and controls. Unconditional logistic regression analysis was used to estimate the association between the genotype frequency and the risk of developing DLBCL.

Table 2. The single nucleotide polymorphisms (SNPs), SNP positions, and primers sequences for IL-6 and IL-10 genes.

\begin{tabular}{cccccc}
\hline SNP-ID & Gene & Chr $^{\wedge}$ & Bp $^{*}$ & Primer Forward & Primer Reverse \\
\hline rs1800795 & IL-6 & 7 & 22727062 & ACGTTGGATGAGCCTCAATGACGACCTAAG & ACGTTGGATGGATTGTGCAATGTGACGTCC \\
rs1800796 & IL-6 & 7 & 22726627 & ACGTTGGATGTCTTCTGTGTCTGGCTCTC & ACGTTGGATGTGGAGACGCCTTGAAGTAAC \\
rs1800797 & IL-6 & 7 & 22726602 & ACGTTGGATGTGGAGACGCCTTGAAGTAAC & ACGTTGGATGTCTTCTGTGTTCTGGCTCTC \\
rs1800871 & IL-10 & 1 & 206773289 & ACGTTGGATGGGTGTACCCTTGTACAGGTG & ACGTTGGATGATGCTAGTCAGGTAGTGCTC \\
rs1800872 & IL-10 & 1 & 206773062 & ACGTTGGATGAAAGGAGCCTGGAACACATC & ACGTTGGATGTCCTCAAAGTTCCCAAGCAG \\
rs1800890 & IL-10 & 1 & 206776020 & ACGTTGGATGCAAGCCCAGATGCATAGTAG & ACGTTGGATGCTGATTTCCCAGTACATCCC \\
rs1800896 & IL-10 & 1 & 206773552 & ACGTTGGATGATTCCATGGAGGCTGGATAG & ACGTTGGATGGACAACACTACTAAGGCTTC \\
\hline \multicolumn{7}{c}{ * bp: base pair (Genomic Position). ^ Chr: Chromosome. }
\end{tabular}

\subsection{Statistical Analysis}

Overall survival (OS) was calculated from the date of diagnosis to the date of death or the last visit for those who were alive at the time of final data collection and analysis. All statistical 
analyses were performed using IBM SPSS Statistics version 20.0 (IBM Corp., Armonk, NY, USA). The clinical characteristics and response rate of the patients were compared using chi-square tests. The Hardy-Weinberg equilibrium (HWE) test was estimated by a goodness-of-fit $\chi^{2}$ test. The Kaplan-Meier method was used to construct survival curves, and the results were compared using a log-rank/Wilcoxon (Gehan) statistic. Multivariate survival was used to control for confounders (age and stage) using Cox regression (Table S4). The association between polymorphism and the risk for DLBCL was calculated using unconditional logistic regression. The survival curves were displayed using Graph Pad Prism 6 software. All significant variables $(p<0.05)$ were entered into a multivariate model to adjust for possible confounders.

\section{Conclusions}

In this study, we demonstrated that in our Jordanian Arab population the risk of DLBCL is not influenced by any of the polymorphisms affecting either the proximal (rs1800872A > C, rs1800890A > $\mathrm{T}, \mathrm{rs} 1800896 \mathrm{~T}>\mathrm{C})$ or the distal $(\mathrm{rs} 1800871 \mathrm{G}>\mathrm{A})$ region of the IL-10 promoter gene $(p=0.81,0.43,0.78$, and 0.76 ; respectively).

The IL-6 rs1800797 was the only SNP to show significant survival results, DLBCL subjects with the codominant model (GG/AG/AA) genotypes and recessive model (AA genotype in comparison with the combined GG/GA genotype) had worse overall survival ( $p=0.028$ and 0.016 , respectively).

Supplementary Materials: The following are available online at http://www.mdpi.com/2072-6694/12/2/382/s1, Table S1: The Hardy-Weinberg equilibrium (HWE) $p$-values for the cases and the controls. Table S2: The Frequency of allele and genotype for seven cytokines related SNPs in DLBCL patients and controls (Case/Control). Table S3: Genotype distribution of the IL-6 and IL-10 in DLBCL patients. Table S4: Multivariate Survival analyses using Cox Regression Model for SNP 1800797 and controlling for Age and Stage. S1: Dataset. S2: Survival analysis.

Author Contributions: Conceptualization and design, S.M.A.-K., N.A. and L.N.A.-E.; data collection, A.-H.A.-M., D.J.Z. and T.Z.K.; data analysis and interpretation, N.A., S.M.A.-K.; manuscript writing, S.M.A.-K. All authors have read and agreed to the published version of the manuscript.

Funding: The study was supported by the Jordan University of Science and Technology Grant number 20170225.

Conflicts of Interest: The authors declare no conflict of interest.

\section{References}

1. Swerdlow, S.H.; Campo, E.; Pileri, S.A.; Harris, N.L.; Stein, H.; Siebert, R.; Advani, R.; Ghielmini, M.; Salles, G.A.; Zelenetz, A.D. The 2016 revision of the World Health Organization classification of lymphoid neoplasms. Blood 2016, 127, 2375-2390. [CrossRef] [PubMed]

2. Siegel, R.L.; Miller, K.D.; Jemal, A. Cancer statistics, 2016. CA 2016, 66, 7-30. [CrossRef] [PubMed]

3. Teras, L.R.; DeSantis, C.E.; Cerhan, J.R.; Morton, L.M.; Jemal, A.; Flowers, C.R. 2016 US lymphoid malignancy statistics by World Health Organization subtypes. CA 2016, 66, 443-459. [CrossRef] [PubMed]

4. Perry, A.M.; Diebold, J.; Nathwani, B.N.; MacLennan, K.A.; Müller-Hermelink, H.K.; Bast, M.; Boilesen, E.; Armitage, J.O.; Weisenburger, D.D. Non-Hodgkin lymphoma in the developing world: Review of 4539 cases from the International Non-Hodgkin Lymphoma Classification Project. Haematologica 2016, 101, 1244-1250. [CrossRef]

5. Ferlay, J.; Soerjomataram, I.; Dikshit, R.; Eser, S.; Mathers, C.; Rebelo, M.; Parkin, D.M.; Forman, D.; Bray, F. Cancer incidence and mortality worldwide: Sources, methods and major patterns in GLOBOCAN 2012. Int. J. Cancer 2015, 136, E359-E386. [CrossRef]

6. Horesh, N.; Horowitz, N.A. Does gender matter in non-Hodgkin lymphoma? Differences in epidemiology, clinical behavior, and therapy. Rambam Maimonides Med. J. 2014, 5, e0038. [CrossRef]

7. Kamangar, F.; Dores, G.M.; Anderson, W.F. Patterns of cancer incidence, mortality, and prevalence across five continents: Defining priorities to reduce cancer disparities in different geographic regions of the world. J. Clin. Oncol. 2006, 24, 2137-2150. [CrossRef]

8. Batista, J.L.; Birmann, B.M.; Epstein, M.M. Epidemiology of Hematologic Malignancies, Pathology and Epidemiology of Cancer; Springer: Berlin/Heidelberg, Germany, 2017; pp. 543-569. 
9. Morton, L.M.; Wang, S.S.; Cozen, W.; Linet, M.S.; Chatterjee, N.; Davis, S.; Severson, R.K.; Colt, J.S.; Vasef, M.A.; Rothman, N.; et al. Etiologic heterogeneity among non-Hodgkin lymphoma subtypes. Blood 2008, 112, 5150-5160. [CrossRef]

10. Ollberding, N.J.; Aschebrook-Kilfoy, B.; Caces, D.B.; Smith, S.M.; Weisenburger, D.D.; Chiu, B.C. Dietary patterns and the risk of non-Hodgkin lymphoma. Public Health Nutr. 2014, 17, 1531-1537. [CrossRef]

11. Crump, C.; Sundquist, J.; Sieh, W.; Winkleby, M.A.; Sundquist, K. Season of birth and risk of Hodgkin and non-Hodgkin lymphoma. Int. J. Cancer 2014, 135, 2735-2739. [CrossRef]

12. Slager, S.L.; Benavente, Y.; Blair, A.; Vermeulen, R.; Cerhan, J.R.; Costantini, A.S.; Monnereau, A.; Nieters, A.; Clavel, J.; Call, T.G.; et al. Medical history, lifestyle, family history, and occupational risk factors for chronic lymphocytic leukemia/small lymphocytic lymphoma: The InterLymph Non-Hodgkin Lymphoma Subtypes Project. J. Natl. Cancer Inst. Monogr. 2014, 2014, 41-51. [CrossRef] [PubMed]

13. Harris, N.; Jaffe, E.; Diebold, J.; Flandrin, G.; Muller-Hermelink, H.; Vardiman, J.; Lister, T.; Bloomfield, C. The World Health Organization Classification of Neoplasms of the Hematopoietic and Lymphoid Tissues: Report of the Clinical Advisory Committee Meeting, Airlie House, Virginia, November 1997. Hematol. J. 2000, 1, 53-66. [CrossRef] [PubMed]

14. Alizadeh, A.A.; Eisen, M.B.; Davis, R.E.; Ma, C.; Lossos, I.S.; Rosenwald, A.; Boldrick, J.C.; Sabet, H.; Tran, T.; $\mathrm{Yu}, \mathrm{X}$.; et al. Distinct types of diffuse large B-cell lymphoma identified by gene expression profiling. Nature 2000, 403, 503-511. [CrossRef]

15. Inglot, A.D. Classification of cytokines according to the receptor code. Arch. Immunol. Exp. 1997, 45, 353-357.

16. Rothman, N.; Skibola, C.F.; Wang, S.S.; Morgan, G.; Lan, Q.; Smith, M.T.; Spinelli, J.J.; Willett, E.; de Sanjose, S.; Cocco, P. Genetic variation in TNF and IL10 and risk of non-Hodgkin lymphoma: A report from the InterLymph Consortium. Lancet Oncol. 2006, 7, 27-38. [CrossRef]

17. Gu, X.; Shen, Y.; Fu, L.; Zuo, H.-Y.; Yasen, H.; He, P.; Guo, X.-H.; Shi, Y.-W.; Yusufu, M. Polymorphic variation of inflammation-related genes and risk of non-Hodgkin lymphoma for Uygur and Han Chinese in Xinjiang. Asian Pac. J. Cancer Prev. 2014, 15, 9177e83. [CrossRef]

18. Nielsen, K.R.; Rodrigo-Domingo, M.; Steffensen, R.; Baech, J.; Bergkvist, K.S.; Oosterhof, L.; Schmitz, A.; Bødker, J.S.; Johansen, P.; Vogel, U. Interactions between SNPs affecting inflammatory response genes are associated with multiple myeloma disease risk and survival. Leuk. Lymphoma 2017, 58, 2695-2704. [CrossRef]

19. Ennas, M.G.; Moore, P.S.; Zucca, M.; Angelucci, E.; Cabras, M.G.; Melis, M.; Gabbas, A.; Serpe, R.; Madeddu, C.; Scarpa, A. Interleukin-1B (IL1B) and interleukin-6 (IL6) gene polymorphisms are associated with risk of chronic lymphocytic leukaemia. Hematol. Oncol. 2008, 26, 98-103. [CrossRef]

20. Domingo-Domènech, E.; Benavente, Y.; González-Barca, E.; Montalban, C.; Gumà, J.; Bosch, R.; Wang, S.S.; Lan, Q.; Whitby, D.; de Sevilla, A.F. Impact of interleukin-10 polymorphisms (-1082 and -3575) on the survival of patients with lymphoid neoplasms. Haematologica 2007, 92, 1475-1481. [CrossRef]

21. Kishimoto, T.; Akira, S.; Taga, T. Interleukin-6 and its receptor: A paradigm for cytokines. Science 1992, 258, 593-597. [CrossRef]

22. Rose, T.M.; Bruce, A.G. Oncostatin $\mathrm{M}$ is a member of a cytokine family that includes leukemia-inhibitory factor, granulocyte colony-stimulating factor, and interleukin 6. Proc. Natl. Acad. Sci. USA 1991, 88, 8641-8645. [CrossRef] [PubMed]

23. Wang, X.; Lupardus, P.; LaPorte, S.L.; Garcia, K.C. Structural biology of shared cytokine receptors. Annu. Rev. Immunol. 2009, 27, 29-60. [CrossRef] [PubMed]

24. Miyajima, A.; Kitamura, T.; Harada, N.; Yokota, T.; Arai, K.-I. Cytokine receptors and signal transduction. Annu. Rev. Immunol. 1992, 10, 295-331. [CrossRef]

25. Sadowski, H.B.; Shuai, K.; Darnell, J.E.; Gilman, M.Z. A common nuclear signal transduction pathway activated by growth factor and cytokine receptors. Science 1993, 261, 1739-1744. [CrossRef]

26. Balkwill, F.; Mantovani, A. Inflammation and cancer: Back to Virchow? Lancet 2001, 357, 539-545. [CrossRef]

27. Hadden, J.W. Immunodeficiency and cancer: Prospects for correction. Int. Immunopharmacol. 2003, 3, 1061-1071. [CrossRef]

28. Karin, M.; Greten, F.R. NF-кB: Linking inflammation and immunity to cancer development and progression. Nat. Rev. Immunol. 2005, 5, 749-759. [CrossRef] [PubMed]

29. Schuler, M.; Huber, C.; Peschel, C. Cytokines in the pathophysiology and treatment of chronic B-cell malignancies. Ann. Hematol. 1995, 71, 57-63. [CrossRef] [PubMed] 
30. Kurzrock, R. Cytokine deregulation in hematological malignancies: Clinical and biological implications. Clin. Cancer Res. 1997, 3, 2581-2584.

31. Blay, J.-Y.; Negrier, S.; Combaret, V.; Attali, S.; Goillot, E.; Merrouche, Y.; Mercatello, A.; Ravault, A.; Tourani, J.-M.; Moskovtchenko, J.-F. Serum level of interleukin 6 as a prognosis factor in metastatic renal cell carcinoma. Cancer Res. 1992, 52, 3317-3322.

32. Seymour, J.F.; Talpaz, M.; Cabanillas, F.; Wetzler, M.; Kurzrock, R. Serum interleukin-6 levels correlate with prognosis in diffuse large-cell lymphoma. J. Clin. Oncol. 1995, 13, 575-582. [CrossRef] [PubMed]

33. O'Brien, S.J.; Nelson, G.W. Human genes that limit AIDS. Nat. Genet. 2004, 36, 565-574. [CrossRef] [PubMed]

34. Lech-Maranda, E.; Baseggio, L.; Bienvenu, J.; Charlot, C.; Berger, F.; Rigal, D.; Warzocha, K.; Coiffier, B.; Salles, G. Interleukin-10 gene promoter polymorphisms influence the clinical outcome of diffuse large B-cell lymphoma. Blood 2004, 103, 3529-3534. [CrossRef] [PubMed]

35. Forrest, M.S.; Skibola, C.F.; Lightfoot, T.J.; Bracci, P.M.; Willett, E.V.; Smith, M.T.; Holly, E.A.; Roman, E. Polymorphisms in innate immunity genes and risk of non-Hodgkin lymphoma. Br. J. Haematol. 2006, 134, 180-183. [CrossRef] [PubMed]

36. Hirano, T.; Yasukawa, K.; Harada, H.; Taga, T.; Watanabe, Y.; Matsuda, T.; Kashiwamura, S.-I.; Nakajima, K.; Koyama, K.; Iwamatsu, A. Complementary DNA for a novel human interleukin (BSF-2) that induces B lymphocytes to produce immunoglobulin. Nature 1986, 324, 73-76. [CrossRef] [PubMed]

37. Boulanger, M.J.; Chow, D.-C.; Brevnova, E.E.; Garcia, K.C. Hexameric structure and assembly of the interleukin-6/IL-6 $\alpha$-receptor/gp130 complex. Science 2003, 300, 2101-2104. [CrossRef]

38. Kolarich, D.; Lepenies, B.; Seeberger, P.H. Glycomics, glycoproteomics and the immune system. Curr. Opin. Chem. Biol. 2012, 16, 214-220. [CrossRef]

39. Kumar, S.; Ingle, H.; Prasad, D.V.R.; Kumar, H. Recognition of bacterial infection by innate immune sensors. Crit. Rev. Microbiol. 2013, 39, 229-246. [CrossRef]

40. Rock, F.L.; Hardiman, G.; Timans, J.C.; Kastelein, R.A.; Bazan, J.F. A family of human receptors structurally related to Drosophila Toll. Proc. Natl. Acad. Sci. USA 1998, 95, 588-593. [CrossRef]

41. Abbas, A.K.; Murphy, K.M.; Sher, A. Functional diversity of helper T lymphocytes. Nature 1996, 383, 787-793. [CrossRef]

42. Aderem, A.; Ulevitch, R.J. Toll-like receptors in the induction of the innate immune response. Nature 2000, 406, 782-787. [CrossRef] [PubMed]

43. Foster, C.B.; Lehrnbecher, T.; Samuels, S.; Stein, S.; Mol, F.; Metcalf, J.A.; Wyvill, K.; Steinberg, S.M.; Kovacs, J.; Blauvelt, A. An IL6 promoter polymorphism is associated with a lifetime risk of development of Kaposi sarcoma in men infected with human immunodeficiency virus. Blood 2000, 96, 2562-2567. [CrossRef] [PubMed]

44. Pawlikowska, L.; Tran, M.N.; Achrol, A.S.; McCulloch, C.E.; Ha, C.; Lind, D.L.; Hashimoto, T.; Zaroff, J.; Lawton, M.T.; Marchuk, D.A. Polymorphisms in genes involved in inflammatory and angiogenic pathways and the risk of hemorrhagic presentation of brain arteriovenous malformations. Stroke 2004, 35, 2294-2300. [CrossRef] [PubMed]

45. Mohlig, M.; Boeing, H.; Spranger, J.; Osterhoff, M.; Kroke, A.; Fisher, E.; Bergmann, M.M.; Ristow, M.; Hoffmann, K.; Pfeiffer, A.F. Body mass index and C-174G interleukin-6 promoter polymorphism interact in predicting type 2 diabetes. J. Clin. Endocrinol. Metab. 2004, 89, 1885-1890. [CrossRef] [PubMed]

46. Ota, N.; Hunt, S.C.; Nakajima, T.; Suzuki, T.; Hosoi, T.; Orimo, H.; Shirai, Y.; Emi, M. Linkage of interleukin 6 locus to human osteopenia by sibling pair analysis. Hum. Genet. 1999, 105, 253-257. [CrossRef]

47. Sawczenko, A.; Azooz, O.; Paraszczuk, J.; Idestrom, M.; Croft, N.M.; Savage, M.O.; Ballinger, A.B.; Sanderson, I.R. Intestinal inflammation-induced growth retardation acts through IL-6 in rats and depends on the-174 IL-6 G/C polymorphism in children. Proc. Natl. Acad. Sci. USA 2005, 102, 13260-13265. [CrossRef]

48. Lan, Q.; Zheng, T.; Rothman, N.; Zhang, Y.; Wang, S.S.; Shen, M.; Berndt, S.I.; Zahm, S.H.; Holford, T.R.; Leaderer, B. Cytokine polymorphisms in the Th1/Th2 pathway and susceptibility to non-Hodgkin lymphoma. Blood 2006, 107, 4101-4108. [CrossRef]

49. Wang, S.S.; Cerhan, J.R.; Hartge, P.; Davis, S.; Cozen, W.; Severson, R.K.; Chatterjee, N.; Yeager, M.; Chanock, S.J.; Rothman, N. Common genetic variants in proinflammatory and other immunoregulatory genes and risk for non-Hodgkin lymphoma. Cancer Res. 2006, 66, 9771-9780. [CrossRef]

50. Talaat, R.M.; Abdel-Aziz, A.M.; El-Maadawy, E.A.; Abdel-Bary, N. CD38 and interleukin 6 gene polymorphism in egyptians with diffuse large B-cell lymphoma (DLBCL). Immunol. Investig. 2015, 44, 265-278. [CrossRef] 
51. Eskdale, J.; Kube, D.; Tesch, H.; Gallagher, G. Mapping of the human IL10 gene and further characterization of the 5'flanking sequence. Immunogenetics 1997, 46, 120-128. [CrossRef]

52. Hovsepian, E.; Penas, F.; Siffo, S.; Mirkin, G.A.; Goren, N.B. IL-10 inhibits the NF-кB and ERK/MAPK-mediated production of pro-inflammatory mediators by up-regulation of SOCS-3 in Trypanosoma cruzi-infected cardiomyocytes. PLoS ONE 2013, 8, e79445. [CrossRef] [PubMed]

53. Zhao, M.; Zhang, R.; Xu, X.; Liu, Y.; Zhang, H.; Zhai, X.; Hu, X. IL-10 reduces levels of apoptosis in Toxoplasma gondii-infected trophoblasts. PLoS ONE 2013, 8, e56455. [CrossRef] [PubMed]

54. Chaouat, G.; Meliani, A.A.; Martal, J.; Raghupathy, R.; Elliott, J.; Elliot, J.; Mosmann, T.; Wegmann, T. IL-10 prevents naturally occurring fetal loss in the CBA $x$ DBA/2 mating combination, and local defect in IL-10 production in this abortion-prone combination is corrected by in vivo injection of IFN-tau. J. Immunol. 1995, 154, 4261-4268. [CrossRef] [PubMed]

55. Cunningham, L.; Chapman, C.; Dunstan, R.; Bell, M.; Joske, D. Polymorphisms in the interleukin 10 gene promoter are associated with susceptibility to aggressive non-Hodgkin's lymphoma. Leuk. Lymphoma 2003, 44, 251-255. [CrossRef]

56. Turner, D.; Williams, D.; Sankaran, D.; Lazarus, M.; Sinnott, P.; Hutchinson, I. An investigation of polymorphism in the interleukin-10 gene promoter. Eur. J. Immunogenet. 1997, 24, 1-8. [CrossRef]

57. Cao, H.-Y.; Zou, P.; Zhou, H. Genetic association of interleukin-10 promoter polymorphisms and susceptibility to diffuse large B-cell lymphoma: A meta-analysis. Gene 2013, 519, 288-294. [CrossRef]

58. Bogunia-Kubik, K.; Mazur, G.; Wrobel, T.; Kuliczkowski, K.; Lange, A. Interleukin-10 gene polymorphisms influence the clinical course of non-Hodgkin's lymphoma. Tissue Antigens 2008, 71, 146-150. [CrossRef]

59. Berglund, M.; Thunberg, U.; Roos, G.; Rosenquist, R.; Enblad, G. The interleukin-10 gene promoter polymorphism (-1082) does not correlate with clinical outcome in diffuse large B-cell lymphoma. Blood 2005, 105, 4894-4895. [CrossRef]

60. Purdue, M.P.; Lan, Q.; Kricker, A.; Grulich, A.E.; Vajdic, C.M.; Turner, J.; Whitby, D.; Chanock, S.; Rothman, N.; Armstrong, B.K. Polymorphisms in immune function genes and risk of non-Hodgkin lymphoma: Findings from the New South Wales non-Hodgkin Lymphoma Study. Carcinogenesis 2007, 28, 704-712. [CrossRef]

61. Lim, Y.-Y.; Chin, Y.-M.; Tai, M.-C.; Fani, S.; Chang, K.-M.; Ong, T.-C.; Bee, P.-C.; Gan, G.-G.; Ng, C.-C. Analysis of interleukin-10 promoter single nucleotide polymorphisms and risk of non-Hodgkin lymphoma in a Malaysian population. Leuk. Lymphoma 2015, 56, 163-168. [CrossRef]

(C) 2020 by the authors. Licensee MDPI, Basel, Switzerland. This article is an open access article distributed under the terms and conditions of the Creative Commons Attribution (CC BY) license (http://creativecommons.org/licenses/by/4.0/). 